\title{
Concepções de felicidade e tragédia na música raiz sertaneja como educação entre sujeitos
}

Antonio de Jesus Santana1, Valéria Oliveira de Vasconcelos ${ }^{2}$

\begin{abstract}
Resumo
O trabalho apresenta resultados de uma pesquisa de mestrado em Educação que teve como objetivo levantar as concepções de "felicidade" e "tragédia" presentes na música raiz sertaneja, identificando algumas canções que portam essas ideias, além de compreender se elas podem ser vistas como elementos de educação entre sujeitos nos domínios da educação popular. A coleta de dados deu-se por meio de rodas de conversa com integrantes de um grupo de violeiros do interior paulista, apoiada na pesquisa participante. A bibliografia baseou-se nas teorias, princípios e conceitos pedagógicos pela perspectiva libertadora, com ênfase na participação do sujeito autônomo. Sob a égide dos sentidos e experiências trazidos pela música raiz sertaneja, apontaram-se caminhos que, por meio de atividades propositivas, reflexivas e organizadas, suscitam práticas educativas no âmbito da educação popular.
\end{abstract}

\section{Palavras-chave}

Música Raiz Sertaneja. Cultura Caipira. Educação Popular.

1. Mestre em Educação pelo Centro Universitário Salesiano de São Paulo, Brasil; professor de Filosofia do Colégio Salesiano São José, Campinas, São Paulo, Brasil. E-mail: antonio.santana@essj.com.br.

2. Pós-doutora em Educação pela Universidade Federal de São Carlos; educadora popular; professora do Centro Universitário Salesiano de São Paulo, Americana, São Paulo, Brasil. E-mail: valvasc2013@gmail.com. 


\title{
Conceptions of happiness and tragedy in the root country music as education among subjects
}

Antonio de Jesus Santana*, Valéria Oliveira de Vasconcelos**

\begin{abstract}
The work presents results of a master's degree research in education that had as objective: to raise the conceptions of "happiness" and "tragedy" present in the root country music, identifying some songs that carry these ideas, and understand if these can be seen as elements of education among subjects in the fields of popular education. The data collection was done by conversation circles with members of a group of guitar players from the interior of São Paulo, supported by participant research. The bibliography was based on pedagogical theories, principles and concepts from the liberating perspective, with emphasis on the participation of the autonomous subject. Under the aegis of the senses and experiences brought by the root coutry music, paths were identified which, through propositive, reflexive and organized activities, gave rise to educational practices within the scope of popular education.
\end{abstract}

\section{Keywords}

Root Country Music. Folk Culture. Popular Education.

* Master in Education, Salesian University Center of São Paulo, State of São Paulo, Brazil; Philosophy teacher at the Salesian College São José, Campinas, State of São Paulo, Brazil. E-mail: antonio.santana@essj. com.br.

** Post-doctorate in Education, Federal University of São Carlos, State of São Paulo, Brazil; popular educator; professor at the Salesian University Center of São Paulo, State of São Paulo, Brazil. E-mail: valvasc2013@gmail. com. 


\section{Introdução}

O presente trabalho traz algumas reflexões sobre uma pesquisa de mestrado em Educação que buscou responder à seguinte questão de estudo: "Como as concepções de felicidade e tragédia, presentes na música raiz sertaneja, podem ser vistas como educação entre sujeitos?".

O sujeito da pesquisa é o "violeiro" (17 homens e 4 mulheres de um grupo de violeiros da cidade de Votuporanga, região noroeste do interior de São Paulo) por ser ele o mediador dos ensinos e aprendizagens tornando-se o veiculador entre a percepção do poeta escritor e o ouvinte destinatário da música ${ }^{3}$.

Seus integrantes são oriundos de famílias de lavradores que viveram do trabalho da terra que, impulsionados pelo êxodo rural, deixaram suas propriedades rurais e se mudaram para a cidade em busca de melhores condições de vida. A maioria deles aprendeu a cantar e tocar a música raiz sertaneja desde suas meninices. Aprenderam empiricamente nos seios de suas famílias que mantinham a tradição da música raiz e da dança da catira na cultura caipira. Aprenderam vendo outros violeiros tocarem e cantarem, além do ouvir músicas pelos programas de radiofonia e do uso de publicações de revistas sertanejas, pelas quais se tinha o acesso às letras.

A preferência pelo estilo da música raiz sertaneja se dá pelas histórias de suas próprias vidas, nas quais o cantar e o dançar historicamente compuseram o lazer, a diversão, o meio de sociabilidade, a expressão e o reconhecimento pessoal. Nesse espaço cultural, cada um gestou, germinou e amadureceu suas histórias de amor, trabalho, religiosidade e expressões artísticas.

Os objetivos da pesquisa foram: a) Levantar entre os sujeitos da pesquisa as concepções de "felicidade" e "tragédia" presentes na música raiz sertaneja; b) Identificar entre eles algumas músicas que portam em suas letras ideias sobre felicidade e tragédia; c) Compreender como estas podem ser vistas como elementos de educação entre sujeitos; 4) Propor possibilidades de articulação entre os dados levantados e as práticas da educação popular.

\section{Repicados da viola: pesquisa participante e a roda de conversa - eficácia entre método e prática no âmbito educativo}

O enfoque metodológico foi o da pesquisa participante. Pautamo-nos pela curiosidade epistemológica de Paulo Freire em estudar como se constroem e se desenvolvem os processos de aprendizagens populares, bem como seus valores. Segundo o educador,

\footnotetext{
Não é a curiosidade espontânea que viabiliza a tomada de distância epistemológica. Essa tarefa cabe à curiosidade epistemológica - superando a curiosidade ingênua, ela se faz mais metodicamente rigorosa. Essa rigorosidade metódica é que faz a passagem do conhecimento do senso comum para o do conhecimento científico. Não é o conhecimento científico que é rigoroso. A rigorosidade se acha no método de aproximação do objeto. A rigorosidade nos possibilita maior ou menor exatidão no conhecimento produzido ou no achado de nossa busca epistemológica (FREIRE, 2003, p. 78):
}

Entendemos que o pesquisador é interlocutor intérprete, mas com o cuidado para não dizer sua voz como referência ao processo da pesquisa. Não com o propósito de "dar a voz" ao sujeito, e sim, pelo diálogo, na roda de conversa, prestar ouvidos à voz do sujeito em sua linguagem, em suas concepções e visão de mundo, constituintes de suas histórias, memórias, saberes e traduzi-los em metodologia.

3. Todos os participantes assinaram um Termo de Consentimento Livre e Esclarecido (TCLE) e concordaram em participar da pesquisa, bem como ter seus nomes verdadeiros publicados. 
O sujeito da pesquisa precisa ter sua voz audível, ressonada, presenciada, personalizada, trazendo-lhe o devido pertencimento da teoria na realidade. Conforme nos diz Brandão (2006b, p. 11):

Conhecer a sua própria realidade. Participar da produção deste conhecimento e tomar posse dele. Aprender a escrever a sua história de classe. Aprender a reescrever a História através da sua história. Ter no agente que pesquisa uma espécie de gente que serve. Uma gente aliada, armada dos conhecimentos científicos que foram sempre negados ao povo, àqueles para quem a pesquisa participante - onde afinal pesquisadores-e-pesquisados são sujeitos de um mesmo trabalho comum, ainda que com situações e tarefas diferentes - pretende ser um instrumento a mais na reconquista popular.

Por essa pontuação, além da confiança na razão e nos procedimentos científicos, mantivemos presentes que também o intuitivo, o mítico, o saber popular são portadores de elementos que constituem o fenômeno educativo na experimentação da realidade.

Utilizamos a roda de conversa como instrumento de coleta de dados, adequandose melhor à proposta de inter-relação dinâmica entre teoria e prática. A roda de conversa é uma prática que porta um potencial educativo que favoreceu o processo da pesquisa. Nos encontros realizados, constatamos que, pela informalidade, os violeiros manifestaram espontaneamente pontos de vista, memória e valores. A roda de conversa tornou-se a situação propícia para desenvolver e incentivar os participantes à curiosidade e à imaginação. Favoreceu a espontaneidade, a alegria, a sociabilidade, as habilidades artísticas, a autoconfiança, o treino de memória e recordações.

$\mathrm{Na}$ roda de conversa, no entorno da pesquisa, a palavra foi livre e não se estabeleceu nenhum critério de ordem das respostas e nem a obrigatoriedade de participação. Os violeiros participantes tiveram liberdade em expressar suas ideias e opiniões sobre os valores cantados nas músicas e os valores culturais caipiras. Nas questões discutidas, algumas vozes apareceram mais que outras, devido a uma maior facilidade na expressão por parte de alguns. No entanto, não notamos a manipulação das vozes, sendo que, nesses casos, suas falas eram legitimadas pela opinião dos demais. A relação entre sujeitos foi de interação, sendo que fomos todos, em algum momento, ouvintes, pesquisadores e participantes.

A partir de temas geradores a roda de conversa torna-se um espaço favorável para elaborar, relacionar e confrontar novos conhecimentos com nossas vivências e conhecimentos anteriores, além de aprendermos a ouvir o ponto de vista e a opinião do outro. A análise musical partiu da realidade do caipira para a sistematização do/s ensino-aprendizagens, transmitidos em suas letras pela utilização de "temas geradores". Geradores porque, segundo Freire (1987), contêm em si a possibilidade de desdobrarse em outros tantos temas (eixos temáticos e subtemas) que, por sua vez, provocam novas tarefas que devem ser cumpridas. Por intermédio de temas geradores e palavras geradoras se torna perceptível à consciência do vivido, fato que favorece a ampliação do conhecimento que os sujeitos têm de sua própria realidade.

\section{O choro da viola: o que se ensina e o que se aprende na música raiz sertaneja}

Podemos afirmar que a música raiz sertaneja produz e expressa algumas das concepções vitais pertinentes à cultura caipira. Essas canções narram e cantam os movimentos da vida que se desenvolvem no sertão, na lida com a terra, com a lavoura, no contato com a natureza e com os valores que fundamentam sua existência cultural. Na instância rural, é 
considerada música de raiz porque, em sua poética e mensagem, canta as peripécias e histórias criadas e vividas nesse entorno cultural. É a voz do homem e da mulher caipira proclamada em sua labuta com a terra, com a vida na terra e com o chão da vida.

Ao objetivar a experiência subjetiva em suas narrativas, a música raiz socializa a individualidade e as experiências humanas. A comunicação tem o poder de influenciar a realidade do sujeito. Afeta tanto o sujeito da experiência quanto as experiências próximas e semelhantes às desse sujeito. Tanto descreve uma condição quanto convoca o sujeito ouvinte a ressignificá-la, renová-la, transferi-la ou mesmo perpetuá-la. Assim, pode se apresentar como ponte entre concepções individuais e coletivas.

Ao analisar a "persistência" da música raiz sertaneja em resistir ao esquecimento e à descontextualização, podemos dizer que isso talvez ocorra porque, em suas narrativas poéticas e mensagens, ela parta do princípio de que a pessoa não suporta ficar fora de si mesma. Alicerçada em suas concepções de simplicidade, vida coletiva e comunitária, poderíamos arriscar a ideia de que a música raiz sertaneja se põe como uma crítica à modernidade que presencia a perda do comunitário. Presenciamos o individualismo limitar o coletivo, e nessa configuração social moderna gera-se a dificuldade da articulação do todo, onde cada um possa se constituir na interação com o outro.

Nossa preocupação, como a de tantos outros estudiosos e pesquisadores, como Whitaker (2002), por exemplo, é que esses conhecimentos possam se perder frente às mudanças socioculturais difundidas pela ideologia pós-moderna da globalização em que o tempo e o espaço, destinados outrora ao ensino-aprendizagem destes saberes, estão já largamente ocupados e substituídos pelo uso de equipamentos eletroeletrônicos e informáticos que enfraquecem a permanência dos valores tradicionais, ou mesmo, os substituem, até nos espaços conservadores da cultura caipira.

Além do esvaziamento dos rituais tradicionais por uma série de fatores, na atualidade o "caipira urbanizado" compra o produto comercializado, do qual outrora detinha o exercício do conhecimento de seus processos constitutivos.

Cabe-nos a tarefa dialógica e reflexiva por meio de círculos, debates, escritos, entre tantas possibilidades, resgatar, preservar, criar e propor, "para" e "com" as pessoas do campo, ou dos espaços urbanos que mantém as tradições caipiras, práticas que valorizem e ressignifiquem sua própria cultura, para as atuais e futuras gerações.

\section{Afinando a viola: arte, música, felicidade e tragédia - representações}

Compreender a influência da arte e da música se torna indispensável para a análise dos temas e palavras geradoras que emergiram da pesquisa a partir da música raiz sertaneja como forma de expressão artística e como propulsora de educação do sujeito caipira. O ser humano em sua última instância deseja, por sua natureza, ser inteiro, total, acabado. Quer ir além do indivíduo separado, parcial, quer plenitude, quer significação.

A arte é indispensável e necessária ao ser humano, pois se apresenta como essencialidade para o equilíbrio das relações homem-nomundo. Essa possibilidade confere ao homem e à mulher expressarem suas relações mais profundas consigo e com tudo o que são capazes de pensar e produzir em seu entorno. O ser humano deseja tornar-se um ser pleno, deseja "ser mais" que o que consegue ser. Ser mais que um indivíduo, um objeto, uma coisa.

Fischer (1981, p. 13), ao descrever a arte como uma necessidade, dizque o homem anseia:

por absorver o mundo circundante, integrá-lo a si; anseia por estender pela ciência e pela 
tecnologia o seu "Eu" curioso e faminto de mundo até as mais remotas constelações e até os mais profundos segredos do átomo; anseia por unir na arte o seu "Eu" limitado com uma existência humana coletiva e por tornar social a sua individualidade.

As manifestações artísticas, dentre outras, a literatura, a música, a pintura, a escultura, a dança, o teatro, portam em si mesmas, os fundamentos do mundo. São taramelas que abrem as janelas da alma para libertar os pensamentos e ideias aprisionados na vontade e nos desejos humanos. A arte, em seu potencial educativo, além de possibilitar ao ser humano satisfação, distração, divertimento, criatividade, prazer, relaxamento, também o situa mediante seus problemas, ajudando-o a identificarse, a reagir face às suas "irrealidades" como se elas fossem suas realidades intensificadas. Permite-lhe "asas" para um voo livre no qual vê a si mesmo, o seu entorno e tudo o mais que seu processo imaginativo alcança.

Na cultura caipira, ainda que não de forma reconhecida nos padrões eruditos de análise, o caipira também produz diversas formas de arte em sua cultura, além da própria viola e da elaboração de letras e músicas, de danças, de cantorias, que se constituem verdadeiras criações artísticas. E nesse movimento, pelo seu poder criativo, pela sua inspiração, se deixa olhar de tal forma que dispõe seu olhar para que outros também possam se ver. Cria um movimento capaz de suprir os autolimites do acontecimento e promover a continuidade dos significados apreendidos e conservados. Neste contexto, consideramos que a música raiz sertaneja é uma legítima portadora dessas funções da arte.

Neste contexto é que propomos práticas educacionais, por exemplo, no âmbito da educação popular, nas quais possa decorrer uma maior horizontalidade entre educador e educando, com privilégios aos saberes individuais e às manifestações culturais da comunidade envolvida.
Nesse sentido, podemos afirmar que, por essas mediações, as práticas educativas ganharão novos olhares, podendo ser registradas, analisadas, teorizadas e sistematizadas. O foco nessa reflexão enriquece e fecunda a educação e a arte. A música se torna uma ótima mediação da arte na educação dentro da comunidade, na qual o cantar poderá ser uma atividade de possíveis ensino-aprendizagens.

\section{Repicados da viola: música raiz sertaneja - contexto cultural}

O caipira comumente é conhecido como "camponês", "caboclo", "caipira", "matuto" "roceiro", "sertanejo". Tais termos portam em si uma diversidade de tratamentos, nomeações e adjetivos, e não raras vezes, preconceitos. De acordo com Brandão (1983, p. 3), o caipira é o homem sem "trato" civilizatório:

Se o seu lugar de vida é o contrário do da cidade e o seu trabalho é invisível, por ser o oposto ao "da cidade", o seu modo de ser e a cultura são o oposto do que a cidade considera "civilização", "civilizado". Por isso, a meio caminho entre o bugre e o branco, o "caipira", "caboclo" é ignorante, "sem trato", ou seja, sem aquilo que, ao ver do tempo, apenas a distância do cativeiro da terra pode atribuir ao homem "de trato", o senhor e seus emissários.

Para o autor, o caipira paulista define-se primeiro por ser naturalmente do lugar onde vive: o campo, a roça, o sertão, a mata, o lugar oposto à cidade. E quem "não mora em povoação" e, portanto, aquele que não possui o preparo e as qualidades do homem da cidade, o civilizador.

Há que se levar em conta que a classificação de modo cultural como "rude e sem trato" pelo ponto de vista da cultura urbana, os marginaliza e cria-lhes um impacto de negação, primeiramente sobre si mesmos e o universo rural. No entanto, há 
que se aprender com eles, sobre eles, sob seu próprio olhar, seus fazeres e a relevância destes fazeres no tecido social que atuam.

A nosso ver, o caipira possui uma forma diferente de ser do "civilizado citadino" mediatizada pelo seu entorno, que não é nem igual, nem inferior e nem superior, e sim, específica e própria. Sob esse ponto de vista é que procuraremos considerar seus afazeres como autoconstituintes. A cultura caipira não representa algo ultrapassado, algo de vitrine fora das margens de sua época, como alguns possam entender e considerar. Ela está tão viva em seus aspectos fundamentais como normalmente o foi. Não se trata de resgatá-la, por que ela nunca esteve perdida. Para Bandini e Dias (2010, p. 9), “o que constitui a historicidade do patrimônio cultural é a memória de um determinado grupo, em que pelo passado se reconhece o seu presente entremeado de permanências e ausências, continuidades e rupturas".

O nosso pensar é que esse estilo musical lembra "raiz", ou seja, música que remete à coisa fixada, que tem solidez, que dá sustento, que amarra, que tem função de alimentar, de transformar, de suportar estruturas. Lembra chão, plantio, colheita, ligação aos ciclos da natureza. Indica cultivo, cultura, seiva, alimento, segurança. Estrutura pela qual distribui a gratuidade do alimento e garantia de condição à vida palpitante e ansiosa por desenvolver-se. Reservatório. Assim, estar enraizado é sinônimo de pertencimento, de fazer parte, de embasarse em valores. É sustentar-se em tradição, em princípios significativos e significantes. Ter raiz é ter base, é estar dentro da própria originalidade, é proclamar-se forte, empoderado, útil, necessário, que vale. Portanto, valente.

A cultura, além de ser a expressão dos indivíduos ou de um grupo, é também um espaço de exercício de cidadania, de conhecimento e reconhecimento. A música é o elemento cultural mais forte pelo qual o artista caipira demonstra sua visão de mundo, suas concepções, crenças, valores. Diante da não linearidade da vida, em nosso entender, as duas polaridades mais contundentes, e em alternâncias, que permeiam acontecimentos, fatos, fenômenos de seu entorno, são os das temáticas da felicidade e da tragédia.

\section{Tinidos da viola: a felicidade e a tragédia}

Nosso pensar é de que a felicidade seja um estado de busca subjetiva da autossatisfação pelo bem viver, que acontece de maneira singular, e alcançá-la, comumente, se apresenta como um desafio para o ser humano. Há certo consenso de que a felicidade seja uma sensação de bem estar e contentamento. Podendo ocorrer por motivos variados, é tida como um estado de quem é feliz, ou ainda, como um momento durável de satisfação, em que o indivíduo se sente plenamente realizado.

Roque Dantas (2008) apresenta a felicidade enquanto representação social, condicionadora das práticas dos atores sociais. Para a autora, a busca pela felicidade orienta a conduta da pessoa em função de sua procura. Denota-se a importância desta para a própria vida, e revela o quanto essa procura influencia as representações sociais.

Entendemos que há uma solicitação ou apelo social à felicidade, seja de forma direta, procurando formas individuais de alcançá-la, ou indireta através da criação de expectativas coletivas que guiam a ação individual. Assim, a felicidade assume o papel de motor da ação social, ainda que sob formas diferenciadas. E questionamos de que forma essas diferentes características podem ser observadas através das práticas, dos valores, da relação com o tempo e dos quadros de vida dos atores sociais. (ROQUE DANTAS, 2008, p. 3).

Portanto, podemos constatar que a felicidade depende do que o indivíduo pensa, do que ele é ou do que tem. Mais que uma estação 
onde se possa chegar, essa sensação de ser feliz é a maneira de se viajar. Depende mais do uso do que se tem, do que o que se falta. Depende muito da consciência de uma finalidade e do alcance do que se busca. Enquanto para alguns a procura da felicidade se dá na busca de coisas materiais, para outros, a felicidade não está na matéria, e sim nas coisas espirituais, e para outros ainda, está nas incitações ao prazer e às alegrias que invadem a vida quotidiana.

Uma das músicas com a temática da felicidade refletida nas rodas de conversa pelos sujeitos da presente pesquisa se chama "Dona felicidade", de autoria de Teddy Vieira e interpretação de Zico e Zeca (1955). Essa moda de viola canta tudo o que o caipira precisava para se sentir feliz: uma casinha onde morar e para onde voltar quando sente saudade, a comida pronta e quente no fogão a lenha, um canarinho cantador na janela, um jardim de encantos e flores perfumadas, uma esposa que correspondia ao seu amor, uma prole de filhos sadios, um cigarrinho para fumar rumo à roça e para cismar à noite, a simplicidade na qual ele e a amada não sentem a falta de nada.

$\mathrm{Na}$ cultura caipira os sentimentos incorporam conhecimento e sabedoria e suportam a ação; mostram-nos também que a felicidade é um sentimento e, como tal, enquanto sentimento tem um papel na orientação da ação. Dentre outras formas, o caipira pela representação em sua música, sentese feliz ao perceber a florada da primavera, ao contemplar a lua cheia, ao ouvir o canto dos pássaros, ao final de uma colheita, ao tocar e cantar com sua viola, ao organizar uma festa. Aqui, interessa mostrar como o sentimento de felicidade motiva a ação dos atores sociais e Ihes condiciona as práticas e comportamentos.

Podemos observar como ocorre essa busca de felicidade pelo caipira por meio da análise da música "Saudade de minha terra", de autoria desconhecida e interpretação de Wilson Pain (2008), que mostra a ruptura do caipira com seu estilo de vida, mudando-se para cidade na tentativa de ser feliz. No entanto, a nova estrutura de vida citadina não permitiu sua completa felicidade, de forma que suas presentes ações levam-no a desejar a volta para sua região e ali refazer todo o seu percurso de vida no trabalho com a terra. Deseja fazer isto para si mesmo e para os outros que não sabem quem ele verdadeiramente é. Encontramos na música a valorização da felicidade oscilando entre dois extremos: ideal e real, ou seja, as opções que se guiam por "ideais", por planos de atuação não pragmáticos e que definem metas de atuação que visam à superação das contingências dessa mesma realidade; e o realismo por planos de atuação construídos sob condições objetivas, pragmáticas e determinadas.

Quanto à sua prática, uns optam por viver uma vida "feliz", outros esperam ou planejam o dia em que serão "felizes". A representação de felicidade e a forma como ela condiciona a ação é produto de uma construção social, diferenciada em função do gênero, idade, processos de socialização, e revelando diferentes graus de reflexividade da ideia de felicidade. (ROQUE DANTAS, 2008).

A música "Lar feliz", composição de Francisco Ávila, interpretação da dupla Tonico e Tinoco (1953), narra a valoração da vida e de tudo o que dela provém e que o caipira conclama ser a felicidade. O canto é um louvor ao encanto pela permanência do si mesmo, continuada em seus filhos. Ao observar e manter a atenção sobre variados rebentos que se dão em novos nascimentos, ele se conscientiza que se eterniza nesse movimento processual contínuo de vida. O caipira, ao lidar com os ciclos de nascimento e morte, transpõe sua leitura de mundo aos da própria natureza humana. Neste contexto, sua visão de mundo é a visão de si mesmo. Em suas experiências, confronta a sabedoria da vida constituída nos aprendizados de seus antepassados, e toma posse dos ensinamentos dados pela 
vida palpitante em todo o seu derredor. Enfim, podemos perceber que a concepção de felicidade em seus diferentes graus e reflexos adquire diferentes significados e traduz-se em diferentes necessidades de concretização. O ser feliz é o simples de tudo, o natural, mas raramente damos conta de tudo o que nos acontece, portanto, podemos sair de uma situação de felicidade e passar a infelicidade, ou seja, a vida se embala como numa gangorra, nos prega peças em movimentos de alternâncias, aos altos e baixos, que às vezes, denominamos tragédia.

Na música raiz sertaneja há uma vasta produção de letras trágicas que, a partir de histórias fictícias, acontecimentos, contos, causos, romances, trazem à tona o universo do amor cantado e ensinado nos enlaces da maternidade, da paternidade, da família, do idoso, e assim por diante. Também são notórias as poesias que evidenciam a violência, a brutalidade, a perseguição e crimes cometidos contra a mulher tanto no entorno caipira quanto no citadino. E por que estas letras são propositivas a determinados aprendizados?

A música "Couro de boi" é um dos clássicos da música raiz sertaneja que sempre fala ao coração, despertando sentimentos inominados nas pessoas. Nessa composição de Teddy Vieira e Palmeira, interpretada por muitas duplas caipiras, dentre elas, Tonico e Tinoco (1950), a narrativa é trágica em alternância de elementos de mimese e de catarse versadas pela história.

A música revela muitos ensinamentos para o contexto cultural do caipira, citaremos alguns que os violeiros apontaram nas rodas de conversa: o cuidado para com o idoso; o direito de comando da mulher nos espaços que lhe era atribuído como de sua responsabilidade; a intolerância; a falta de diálogo nas resoluções dos problemas familiares; a percepção da criança nos aprendizados pelos acertos e erros dos outros; o papel do homem na definição e regulação dos comportamentos familiares; a configuração de ditados como: a mão que dá, não é a mesma que recebe; não faça aos outros o que não quer que os outros lhe façam; pagar com a mesma moeda. Percebemse também as relações de trocas simbólicas entre pais e filhos na manutenção de valores. $\mathrm{O}$ consciente dominando o inconsciente; o racional subordinando o temerário; o inesperado domesticando o passional. Para o filósofo grego Aristóteles (1991), a tragédia é a imitação de uma ação e se executa mediante personagens que agem e que diversamente se apresentam, conforme o próprio caráter e pensamento (porque é segundo estas diferenças de caráter e pensamento que nós qualificamos as ações). Neste aspecto é que se encontra a potencialização educativa da música raiz sertaneja que, quando trata de uma tragédia, as pessoas conseguem tirar lições de vida em sua narrativa, ainda que fictícia. Nesse universo encontramos narrativas trágicas no cotidiano do caipira em seu trabalho, relacionamentos, aventuras, casamento, enfrentamento de intempéries, caçadas, perseguições, vinganças, festas, identidade, dentre outros. No contexto da tragédia, a clássica música "Cabocla Teresa", de composição de Raul Torres e João Pacífico, interpretação de Raul Torres e Serrinha (1940), mostra como os conflitos domésticos eram tratados nas formas de brutalidade e violência contra a mulher. A sugestiva letra trágica nos leva a relevantes questionamentos: Será mesmo que podemos dizer que isso é coisa do passado? Esta tragédia não nos deveria remeter aos porquês de, ainda em nossos dias, milhares de Terezas, nos "por aí da sociedade", balbuciarem, em suas realidades, os mesmos gemidos desta cabocla caipira? Por que os estampidos dos quase 80 anos passados não se silenciam? Por que o "Sr. doutô" só chega depois e, ainda como antes, só quando chamado?

Parece-nos que mesmo em nossos tempos, e ainda dentro de casa, encontramos a "Tereza" independentemente de onde mora, 
idade ou estado civil, vítima do sangue que ferve nas veias, do pai de criação e/ou padrasto enquanto criança; do marido ou ex-marido, quando adulta, e não raras vezes, dos próprios filhos ou cônjuges, sofrendo maus tratos, já idosa.

A tragédia é catártica, pois permite contemplar a vida em sua realidade desvelada, ou seja, sem os "véus" com os quais nos acobertamos para suportar as dores "nuas e cruas". O ser humano se vê tal como é, despido de sua roupagem sociocultural. $\mathrm{Na}$ música "Chico Mineiro", de autoria de Tonico e Francisco Ribeiro, interpretação de Tonico e Tinoco (1947), podemos acompanhar esses movimentos teorizados por Aristóteles. A tragédia propicia pela representação da vida, o "reconhecimento" como passagem do ignorar ao conhecer, que se faz para amizade ou inimizade das personagens que estão destinadas para a dita ou para a desdita.

Um dos dados apresentados como incisivo pela pesquisa é que a narrativa trágica prende mais atenção do ouvinte, que normalmente para de conversar e passa a escutar a história: a pesquisa concluiu que o povo parece prestar mais atenção quando canta uma música de tragédia, por que parece que aquela história fica no pensamento da pessoa, como afirma um dos participantes:

Cantando uma música trágica parece que as pessoas se identificam mais com o negativo do que com o comportamento desejável; as pessoas pensam na história da moda e fica esperando o final para confirmar o que deu errado, onde que tá o erro nas atitudes, e aprende com aquilo ali (PARTICIPANTE A, 2017).

De acordo com Bocayuva (2007), aprender a viver por meio da tragédia seria, portanto, aprender a estar pronto para descobrir mais uma vez o caminho que leva até onde já se está, ou seja, viver vivendo. Assim como nas histórias trágicas, a vida se autocopia. Cada pessoa descobre seu papel na vida somente na medida em que vive. Só se é, ao se tornar e ao tornar-se. Só se descobre sobre a vida nos trâmites vivenciais. Cada um de nós é um fio trágico na trama do tecido da existência. Marcada pela visão da superioridade cultural citadina, a música "Tristeza do Jeca" de composição de Angelino de Oliveira (1919), e interpretada dentre outros, por Tonico e Tinoco (1945), foi uma das primeiras músicas raiz a serem gravadas, e se tornou um ícone. Ela reproduz a vida difícil e penosa do Jeca, que fundado em um estado de nostalgia, fica a gemer suas dores e padecimentos. Todo seu entorno se pinta pelos matizes da tristeza. Entre lamúrias canta e conta para sua amada (provavelmente da cidade) seus desgostos e paixões. Não se percebendo, tudo o mais que via a sua volta também se tornava seu reflexo. Tudo era tão triste quanto o como Ihe disseram que era. O que via era como um espelho da feiura que colocaram a sua frente. Assim prospera a sua imagem, que sua própria música se encarrega de veicular na cidade. Enxergava-se com os olhos dos outros, que o negavam e o consideravam rústico, atrasado, gente do mato. Mesmo sendo a viola a sua única companheira e forma de expor suas mazelas, ao silenciá-la, silencia também sua voz interna e se entrega ao determinismo conformista. Ora, se por um lado esse olhar sobre si mesmo e sua cultura marca o caipira pela inferioridade e subordinação, no qual atesta a nulidade de seu conhecimento como bom e válido, por outro, algumas músicas, causos, crendices e lendas, também o mostram forte, mediante o vasto conhecimento de seu universo na lida com a natureza, com a lavoura, com os ensinamentos ético-morais. $E$ aqui reside exatamente o que queremos preservar.

Visto como a felicidade e a tragédia medeiam à poética musical caipira, apontando seus elementos potenciais à prática de educação, passaremos aos fundamentos do fazer-se da pesquisa, do horizonte a ser mirado. 


\section{Entre ponteios e repicados da viola, 0 toque da educação popular}

Freire (1987) afirma que, apesar de o ser humano não ser determinado, ele está sujeito a condicionamentos pelo contexto histórico e sociocultural de onde vive. Mas o potencial da existência humana está em ter consciência de seus condicionamentos. Por meio de uma visão crítica da realidade, cabeIhe enfrentar as situações-limite, superandoas por meio da luta solidária e coletiva pela transformação das realidades condicionantes.

O caminho da educação é o que se apresenta na melhor possibilidade de transformação existencial. Pela ação educativa, o sujeito se autoconstrói e se autorregula, e a música raiz sertaneja poderá ser articulada em práticas da educação popular por serem propositivas ao saber do indivíduo e da comunidade onde se inserem, e ser uma aliada aos processos educativos e de cidadania.

Diversas poesias sertanejas propõem a participação na qual cada indivíduo possa se ver nesse processo, e por meio dele, a sua tomada de consciência. Em poesias cantadas em músicas como "Porta do mundo", composição de Pião Carreiro e Zé Paulo, interpretação de Tião Carreiro e Pardinho (1986), vemos a afinidade com a viola, e por meio dela, a evocação de concepções de mundo, vida, natureza, religiosidade dentre outras. $\mathrm{O}$ saber de si conjuga-se em um saber consciente, situado, histórico, libertário, poético e autônomo.

Na poesia da música "No rancho fundo", composição de Ary Barroso e Lamartine Babo, interpretação de Chitãozinho e Xororó (1987), notamos a crise existencial do caipira frente a modelos culturais diversos em que a desestabilidade de seus valores lhe impõe uma nova consciência, a qual, Ihe exigirá rompimentos e reformulações de estruturas internas e externas.

$\mathrm{Na}$ música "Vide vida marvada", composição e interpretação de Rolando Boldrin
(1981), notamos que esse processo de tomada de consciência poderá se dar de forma dialógica. Não em qualquer forma de diálogo, mas possível de ser verdadeiro, preciso, aberto e construtivo. O caipira filosofa a natureza, os fenômenos do seu entorno e recursa empiricamente a metafísica tecida entre o si, o mundo, a poesia e sua viola.

As atividades vivenciadas com prazer e em local agradável entre os participantes geram espaços educativos e funcionam como prática de vivência social. Pelo contato com o coletivo o sujeito estabelece e forma laços afetivos. Conforme Freire (2001), as relações na educação devem proceder de contextos que acolham as práticas educativas como práticas sociais e devem continuar por meio de suas múltiplas atividades em contextos educativos em si mesmos. Aprender e ensinar faz parte da existência humana, histórica e social, como dela fazem parte a criação, a invenção, a linguagem, o amor, o ódio, o espanto, o medo, o desejo a atração pelo risco, a fé, a dúvida, a curiosidade, a arte, a magia, a ciência, a tecnologia. E ensinar e aprender, criando todas estas atividades humanas. A educação, pela ótica de Freire (2001, p. 12), é "um dos elementos essenciais para o desenvolvimento humano". Desta maneira, a educação "deve ser algo construído na relação do cotidiano o qual está em transformação a todo o momento". Como elemento de formação para a cidadania, a educação se caracteriza pela forma de transmissão de saber e cultura. Por meio de atividades educativas, os indivíduos podem melhor compreender o mundo e, pelas próprias ações, fazer intervenções como sujeitos construtores de cidadania. Na educação popular, Brandão (2006a) afirma que o conhecimento se caracteriza e se realiza por intermédio de todas as situações em que, a partir da reflexão sobre a prática de movimentos sociais e movimentos populares, as pessoas trocam experiências, recebem informações, criticam ações, refletem sobre as 
situações e aprendem. As atividades pedagógicas vão além de um trabalho coletivo em si mesmo, tornando-se momentos em que a vivência do saber compartido cria a experiência do poder compartilhado.

A educação popular é uma prática social. Melhor, é um domínio de convergência de práticas sociais que têm a ver, especificamente, com a questão do conhecimento. Com a questão da possibilidade da construção de um saber popular. Da apropriação, pelas classes populares, do seu próprio saber. Aquilo que é a fala e a lógica que traduzem a passagem de sujeitos e classes econômicas, para sujeitos e classes políticas. (BRANDÃO, 2006a, p. 92).

A educação popular como fenômeno cultural porta práticas de ações educacionais libertárias. É na consolidação da práxis educativa que ela apresenta sua especificidade e seu processo de conhecimento e de humanização de homensedemulheressociais, históricos, situados.

Educação como processo de humanização, um ato político, de conhecimento e de criação, que ocorre no diálogo entre seres humanos, sujeitos de sua vida, e que, solidariamente, fazem e refazem o mundo. Ao falarmos de educação popular, não estamos nos referindo à educação das classes populares, mas à educação com as classes populares, com elas compromissada e com elas realizada, mediante o diálogo. (VASCONCELOS; OLIVEIRA, 2009, p. 136).

A nosso ver, as autoras apontam o caminho, pois o que se faz necessário, na realidade, é a ação do educador popular junto a esses grupos para o despertar da consciência de que essas possibilidades são factíveis e que eles próprios podem gerenciá-las. A diversidade de agremiações como os grupos de violeiros, catireiros, corurueiros, repentistas, foliões de reis, declamadores, contadores de causos e de histórias, entre outros, presentes nas práticas de cultura caipira, são favoráveis às ações reflexivas e de aprendizagens.

Nos espaços da educação popular como forma de mobilizar, conscientizar e comunicar aspectos da cultura, das lutas sociais, econômicas e políticas, a arte é facilitadora da inserção do sujeito na realidade de forma crítica e criadora, e com finalidade do sujeito emancipar-se das formas pejorativas, excludentes e alienantes que a sociedade competitiva impõe sobre si. Eis o porquê apontarmos a música raiz sertaneja ao categorizar-se como fonte formativa de concepções de patriotismo, educação, dever moral, respeitabilidade, igualdade, direitos e deveres.

\section{Botando a viola no saco: considerações finais}

Buscamos entender como a ideia de felicidade e de tragédia permeiam a cultura caipira por intermédio do que canta, do que celebra, do como convive, do como se vê; como se percebe e como vê os olhares que têm sobre si e seu entorno. Percebemos que o caipira é possuidor de uma cultura rica em manifestações cheias de humanidades, solidariedade, amor à natureza, encantos, simplicidade e apelos à vida, vive e transmite ensino aprendizagens em consonância com entorno cultural. Pela análise da práxis educativa, nas experiências culturais da sociedade rural, pode estimular a propositividade da música raiz sertaneja nas práticas da educação popular. Seja por meio do resgate memorial e afetivo (recordar é viver); seja pelo estimular história de vida, memórias afetivas e consciência; seja pelas lembranças que as músicas trazem para a historicidade individual e coletiva dos sujeitos; seja pela consciência e ressignificação das experiências.

Propomos que esses ponteios e repicados seriam alguns possíveis indicativos da educação libertadora, reflexiva, protagonista, por exemplo, como articular a construção da identidade 
individual e da identidade coletiva. O papel do educador nesse processo é reconhecer os princípios norteadores da ação educativa; busca pela autonomia social a partir da autonomia individual; estratégias para os tipos de conhecimento que é possível construir na prática da educação sociocomunitária e da educação popular; quais as contribuições dessa prática na construção da autonomia e emancipação dos sujeitos nela envolvidos, dentre outros.

"Botar a viola no saco" e ir para outras paragens, longe do comum da expressão, indicando o relaxar das tarraxas em desafino às melodias até aqui tocadas, em um sinal de missão cumprida, ou de um tempo passado que não volta mais, é firmar que a harmonia da viola deve ressonar onde ainda não foi ouvida e, principalmente, onde ela anda caindo no descrédito e esquecimento, tomada por sons de outros instrumentos que cantam as vicissitudes da educação e da vida.

Percebe-se que nestas possibilidades apontadas, tais práticas de educação propõem experiências de intersubjetividades, laços sociais e comunitários. Eis o porquê de afirmamos estar no âmago das propostas educativas da educação popular

\section{Referências}

ARISTÓTEleS. Ética a Nicômaco. Poética. 4. ed. São Paulo: Nova Cultural, 1991. 377 p. (Os pensadores; v. 2).

BANDINI, C. A. P.; DIAS, F. de F. Na trilha da cultura caipira: cantadores, tocadores e declamadores no interior de São Paulo. São Carlos: RiMa, 2010.

BOCAYUVA, I. Sobre a catarse na tragédia grega. In: SEMINÁRIO OUSIA DE ESTUDOS CLÁSSICOS: A POÉTICA DE ARISTÓTELES, 3., 2007, Rio de Janeiro. Anais... Rio de Janeiro, 2007. p. 1-52.

BRANDÃO, C. R. Os caipiras de São Paulo. 1983. Disponível em: < http://www.sitiodarosadosventos. com.br/livro/images/stories/anexos/caipiras_sao_paulo.pdf>. Acesso em: 10 mar. 2018.

O que é educação popular. São Paulo: Brasiliense, 2006a. 95 p. (Coleção Primeiros Passos).

A pesquisa participante e a participação da pesquisa: um olhar entre tempos e espaços a partir da América Latina. In: BRANDÃO, C. R.; STRECK, D. R. (Org.). Pesquisa participante: o saber da partilha. Aparecida: Ideias \& Letras, 2006b. p. 21-54.

FISCHER, E. A necessidade da arte. 9. ed. Rio de Janeiro: J. Zahar, 1981. 258 p.

FREIRE, P. À sombra desta mangueira. 5. ed. São Paulo: Olho d'Água, 2003. 224 p.

Pedagogia do oprimido. 22. ed. São Paulo: Paz e Terra, 1987. 253 p.

Política e educação: ensaios. 5. ed. São Paulo: Cortez, 2001. 144 p. (Coleção Questões

de Nossa Época; v. 23). 
ROQUE DANTAS, A. Que vida viver? Uma análise sociológica da felicidade. In: CONGRESSO PORTUGUÊS DE SOCIOLOGIA "MUNDOS SOCIAIS: SABERES E PRÁTICAS", 6., 2008, Lisboa. Anais... Lisboa: Associação Portuguesa de Sociologia, 2008.

VASCONCELOS, V. O. de; OLIVEIRA, M. W. Educação popular: uma história, um que-fazer. Educação Unisinos, São Leopoldo, v. 13, n. 2, p. 135-146, maio/ago. 2009.

WHITAKER, D. C. A. Sociologia rural: questões metodológicas emergentes. Presidente VenceslauSP: Letras à Margem, 2002. $256 \mathrm{p}$.

Submetido em 20 de março de 2018.

Aprovado em 10 de maio de 2018. 